\title{
STUDY IN THE STRUCTURAL BEHAVIOR OF PRECAST LINING OF A LARGE DIAMETER MULTIFUNCTIONAL TUNNEL PERFORMED BY MEANS OF FINITE ELEMENTS ANALYSIS WITH RESPECT TO SAINT-PETERSBURG GEOLOGICAL CONDITIONS
}

\author{
A. P. LEDYAEV ${ }^{1}$, V. N. KAVKAZSKY ${ }^{1, *}$, T. V. IVANES ${ }^{1}$, A. V. BENIN ${ }^{1}$ \\ Emperor Alexander I St. Petersburg State Transport University, 9, Moskovsky ave., St. Petersburg, \\ 190031, Russia. \\ corresponding author: kavkazskiy_vn@mail.ru.
}

\begin{abstract}
The tunneling technologies are constantly evolving, with the large diameter multifunctional city tunnels becoming more and more common. By building tunnels of large diameters in urban areas one can rationally distribute traffic flows within the unified space and combine various modes of transport. However, such scalable transport construction projects imply a serious pressure both on social aspects of the big cities life and on the city environment. So, in order to make a decision one needs to perform a comprehensive analysis. The authors have analyzed the foreign experience in large diameter tunneling to assess whether it is viable to use these kinds of structures under the geological conditions of St. Petersburg.
\end{abstract}

\author{
Keywords: \\ Transport tunnel; \\ Finite elements analysis; \\ Stress-strain behavior of the \\ lining.
}

\section{Introduction}

In the current shield tunneling practices the most common is construction of combined transport tunnels, which allows to locate several modes of transport within a single cross-section and to utilize underground space in a more rational way. However, since the late 1990s a boom has been seen globally in large diameter tunneling. To develop such ambitious projects special solutions have been worked out that helped to construct large diameter tunnels even under complicated geological, hydrological and urban conditions. Such tunneling excavations are made with the use of highproductivity tunneling systems comprising of mechanical shields with active pressure balance in the digging face and highly waterproof linings with profiled sealing boxes.

\section{Current trends in tunneling over the globe}

Recently all world records in tunneling lining diameters have been beaten. In Russia, a doubledeck highway tunnel of $19.00 \mathrm{~m}$ diameter in St. Petersburg should have been called the winner among the large diameter tunnels. The project of the shield for this tunnel was designed by the German company Herrenknecht. However, the tunneling project has not been implemented. The global trends in tunneling show that this sphere of engineering is being actively developed. In the last decade more than 15 significant projects were realized (the most valuable are showed in Table 1), the $17.6 \mathrm{~m}$ diameter Tuen Mun - Chek Lap Kok tunnel in Hong Kong being among them. Not only does the grandeur of the project make a strong impression, but also a large number of innovations used by Dragages Hong Kong company while tunneling. The $4.6 \mathrm{~km}$ tunnel is excavated at the depth of $50 \mathrm{~m}$ under sea level within the alluvial deposits. 
Table 1: The most impressive tunneling projects $[1,2,3]$.

\begin{tabular}{|c|c|c|c|c|}
\hline $\begin{array}{l}\text { Date/ } \\
\text { Launch }\end{array}$ & Country & $\begin{array}{c}\text { Project } \\
{ }^{*}=\text { Tunnel Talk article }- \text { See } \\
\text { References below }\end{array}$ & TBM manufacturer & Diameter \\
\hline 2017 & USA & $\begin{array}{c}\text { Alaskan Way highway replacement } \\
\text { tunnel* }\end{array}$ & 1 Hitachi Zosen EPBM & $17.48 \mathrm{~m}$ \\
\hline 2018 & $\begin{array}{l}\text { Hong } \\
\text { Kong }\end{array}$ & $\begin{array}{l}\text { Tuen Mun - Chek Lap Kok } \\
\text { subsea highway link }\end{array}$ & 1 Herrenknecht Mixshield & $17.6 \mathrm{~m}$ \\
\hline 2016 & Italy & Santa Lucia Highway Tunnel, & & \\
\hline 2015 & China & $\begin{array}{l}\text { Wuhan Metro road } / \text { metro river } \\
\text { crossing }^{*}\end{array}$ & 2 Herrenknecht Mixshields & $15.76 \mathrm{~m}$ \\
\hline 2013 & China & Shouxhiou Lake Highway Tunnel & $\begin{array}{l}1 \text { Herrenknecht Mixshield } \\
\text { Ex-Nanjing Machine }\end{array}$ & $14.93 \mathrm{~m}$ \\
\hline 2013 & Italy & Caltanissetta highway tunnel, Sicily* & 1 NFM Technologies & $15.08 \mathrm{~m}$ \\
\hline 2011 & China & $\begin{array}{c}\text { Shanghai West Changjiang Yangtze } \\
\text { River Road Tunnel }\end{array}$ & $\begin{array}{c}1 \text { Herrenknecht Mixshield } \\
\text { Ex-Shanghai Changjiang highway } \\
\text { tunnel Project }\end{array}$ & $15.43 \mathrm{~m}$ \\
\hline 2013 & $\begin{array}{c}\text { New } \\
\text { Zealand }\end{array}$ & $\begin{array}{c}\text { Waterview highway connection, } \\
\text { Auckland* }\end{array}$ & 1 Herrenknecht EPBM & $14.41 \mathrm{~m}$ \\
\hline 2011 & China & Weisan Road Tunnel, Nanjing* & $\begin{array}{c}2 \mathrm{IHI} / \text { Mitsubishi/CCCC slurry } \\
\text { TBMs }\end{array}$ & $14.93 \mathrm{~m}$ \\
\hline 2012 & China & Shanghai Hongmei Road & 1 Herrenknecht Mixshield & $14.93 \mathrm{~m}$ \\
\hline 2011 & Italy & A1 Sparvo highway tunnel ${ }^{*}$ & 1 Herrenknecht EPBM & $15.55 \mathrm{~m}$ \\
\hline 2010 & Spain & Seville SE-40 Highway Tunnels* & 2 NFM Technologies EPBMs & $14.00 \mathrm{~m}$ \\
\hline 2010 & China & $\begin{array}{c}\text { Hangzhou Qianjiang Under River } \\
\text { Tunnel }\end{array}$ & $\begin{array}{c}1 \text { Herrenknecht Mixshield Ex- } \\
\text { Shanghai Changjiang highway } \\
\text { tunnel Project }\end{array}$ & $15.43 \mathrm{~m}$ \\
\hline $\begin{array}{l}\text { Design } \\
\text { started } \\
2009\end{array}$ & Russia & Orlovsky Tunnel, Saint Petersburg* & $\begin{array}{l}1 \text { Herrenknecht Mixshield } \\
\text { Project on hold }\end{array}$ & $19.00 \mathrm{~m}$ \\
\hline
\end{tabular}

Another audacious tunnel with the length of $3.2 \mathrm{~km}$ and the diameter of $17.48 \mathrm{~m}$ is being built in Seattle, Washington, USA. The construction was launched in July 2013, and has been done with Hitachi shield, which used to be the world's largest then. Excavations were performed along the gulf shore in weak uncompacted silt and clayey soil. Several delays having occurred, the excavation work was finished in April 2017, and the tunnel now is due to be opened for double-deck motor car traffic in February, 2019 (Fig. 1).

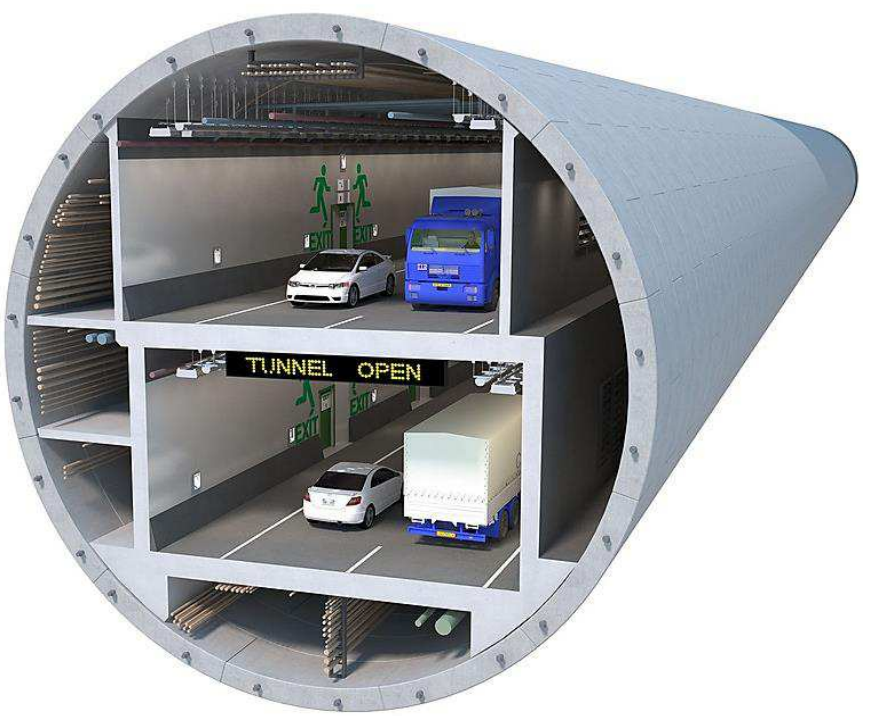

Fig. 1: Cross-section diagram of a tunnel under construction in Seattle, USA. 
The statistical data being analyzed, it became obvious that in spite of all troubles associated with large diameter tunneling and its high cost the interest in such developments is constantly increasing. The same is true for the products of major excavation equipment manufacturers, as their facilities are strongly required for implementing ingenious projects in complicated geological, hydrological and urban conditions.

So, what are the advantages of the combined tunnels with large diameters?

As far as operation and maintenance are concerned, the large diameter tunnels are beneficial because they help to optimize underground space utilization and to separate traffic flows. Large crosssection allows to apply modern approaches to locating transport zones within the single space, which in its turn helps to separate urban transport from heavy freight vehicles, to make provisions for transit corridors at toll roads, to combine railway and highway transport, and, as showed by a tunnel in Malaysia, to use a part of a tunnel as an overflow for storm drains. Various kinds of tunnel crosssection layout are presented in Table 2.

Modern large diameter shields support the power-driven replacement of working head cutters using mechanic arms instead of sending staff to the high pressure area in the machine face, which simplifies maintenance procedures. Apart from that, an improved design of sealings between the shield rear and the tunnel lining allows to excavate at rather high ground water pressure up to $17 \mathrm{~atm}$.

And finally, the biggest benefit brought by large diameter tunnels is an opportunity to locate emergency escape ways within the tunnel cross-section avoiding interconnections between tunnels. It is especially important when building underwater tunnels in complicated geological conditions.

Thus, constructing large diameter underwater tunnels in St. Petersburg can be considered viable, however, a good feasibility study and thorough geological analysis should be provided. At the same time one should remember that applying such solutions requires a research in the effect produced by a change in geological conditions along the large diameter tunnel route on the stressstrain behavior of precast lining, both at construction and at operation phase.

Table 2: Variants of tunnel cross-section layout [1, 2, 3].

\begin{tabular}{|c|c|c|c|c|}
\hline Location & $\begin{array}{l}\text { Shield } \\
\text { diameter }\end{array}$ & Shield type & Application & Tunnel cross-section \\
\hline $\begin{array}{l}\text { Kuala- } \\
\text { Lumpur, } \\
\text { Malaysia }\end{array}$ & $13.21 \mathrm{~m}$ & Mixshield & $\begin{array}{l}\text { Highway transport and } \\
\text { storm drains }\end{array}$ & \\
\hline $\begin{array}{l}\text { Moscow, } \\
\text { Russia }\end{array}$ & $14.20 \mathrm{~m}$ & Hydroshield & $\begin{array}{c}\text { Highway transport and } \\
\text { metro }\end{array}$ & \\
\hline $\begin{array}{l}\text { Nanyang, } \\
\text { China }\end{array}$ & $14.93 \mathrm{~m}$ & Hydroshield & $\begin{array}{c}\text { Highway transport and } \\
\text { utilities }\end{array}$ & \\
\hline $\begin{array}{l}\text { Madrid, } \\
\text { Spain }\end{array}$ & $15.20 \mathrm{~m}$ & $\begin{array}{l}\text { Earth pressure } \\
\text { balance shield }\end{array}$ & $\begin{array}{l}\text { Highway and railway } \\
\text { transport }\end{array}$ & \\
\hline
\end{tabular}




\begin{tabular}{|c|c|c|c|}
\hline $\begin{array}{c}\text { Shanghai, } \\
\text { China }\end{array}$ & $15.43 \mathrm{~m}$ & Hydroshield & $\begin{array}{c}\text { Highway transport and } \\
\text { utilities }\end{array}$ \\
\hline Sparvo, Italy & $15.62 \mathrm{~m}$ & $\begin{array}{c}\text { Earth pressure } \\
\text { balance shield }\end{array}$ & $\begin{array}{c}\text { Highway transport and } \\
\text { utilities }\end{array}$ \\
\hline
\end{tabular}

\section{Statement of the problem and finite elements pattern}

Given that tunnels are constructed with highly waterproof linings equipped with profiled sealing boxes at joints, the stress-strain behavior of a lining was analyzed on the basis of precast structure having $19.00 \mathrm{~m}$ wide outer diameter and consisting of 12 reinforced concrete units connected by inclined rifled rods at longitudinal and transverse joints. The unit is $700 \mathrm{~mm}$ high with a $2200 \mathrm{~mm}$ wide ring. All units are made of Class B50 concrete.

To assess the lining stress-strain behavior we used a numerical method of calculation, namely the finite elements analysis (FEA) [7]. The computational model of the lining and the enclosing soil is presented in Fig. 2.

At the computational model both the soil and the lining are simulated with solid prismatic finite elements, whereas rifled rods are simulated with bar elements having some common nodes with the lining.

In the cross-section the dimensions of the selected soil area are $56 \mathrm{~m} \times 59.2 \mathrm{~m}$. In longitudinal direction the soil element length is determined by the width of the two lining rings and equals $4.4 \mathrm{~m}$. As the task is symmetrical relative to $Y Z$ plane, the calculation deals with a half of the support structure and the enclosing soil of the following sizing: $56 \mathrm{~m} \times 29.6 \mathrm{~m} \times 4 \mathrm{~m}$.

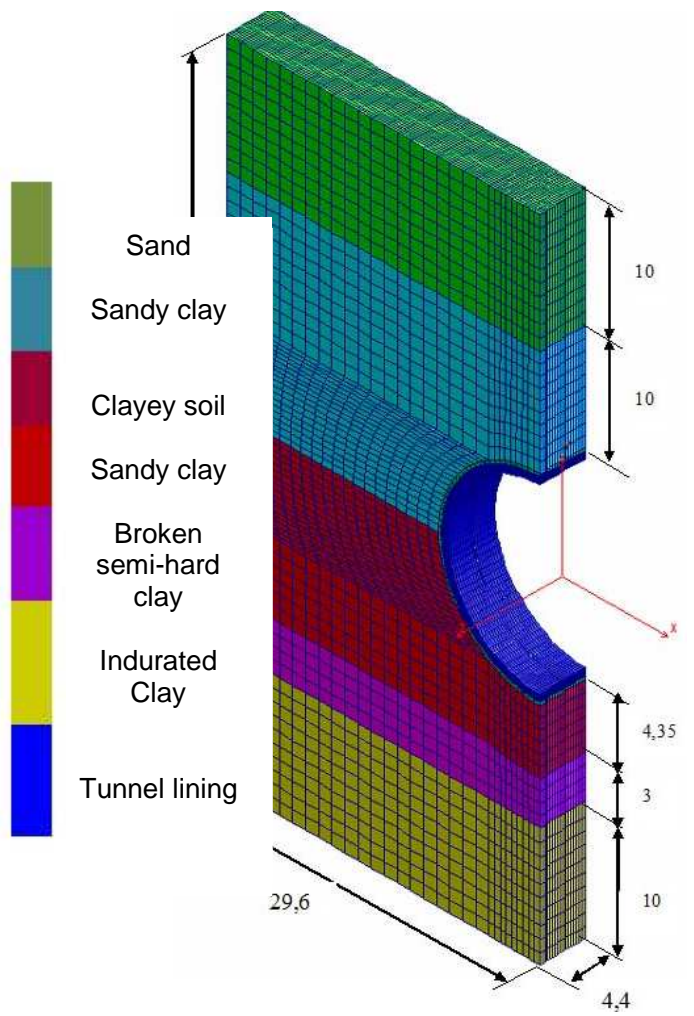

Fig. 2: The lining and the enclosing soil computational model. 
Calculations deal with the underflow cross-section of the route having the deepest location of the tunnel within water-inundated sands, sandy clays and clayey soils. Below there are broken semihard clays with interburdens as well as indurated clays. The thickness of ground above the lining apex is $20.0 \mathrm{~m}$.

Boundary conditions are as follows: no movements along the bottom surface, no turning angles and offsets along $X$ and $Z$ axes of corresponding lateral surfaces, no turning angles around $X$ and $Y$ axes and no movements along $X$ axis in $Y Z$ task symmetry plane.

For calculation purposes the two lining rings were analyzed that had been assembled with account of joints bonding (Fig. 3). The longitudinal joints were simulated according to their structure: the contact surface of simulated adjacent units was set $F=0.75 \mathrm{~m}^{2}$; and the stress-strain properties of concrete in the contact area were taken in a variety accounting for possible plastic hinges in the joint and specified against the joint stiffness coefficient [8]. The joint stiffness coefficient was simulated on the basis of the dimensions and the stress-strain properties of the surfaces in contact. Three options were considered for the joint stiffness: $K=1, \quad K=0.5, K=0.1$.
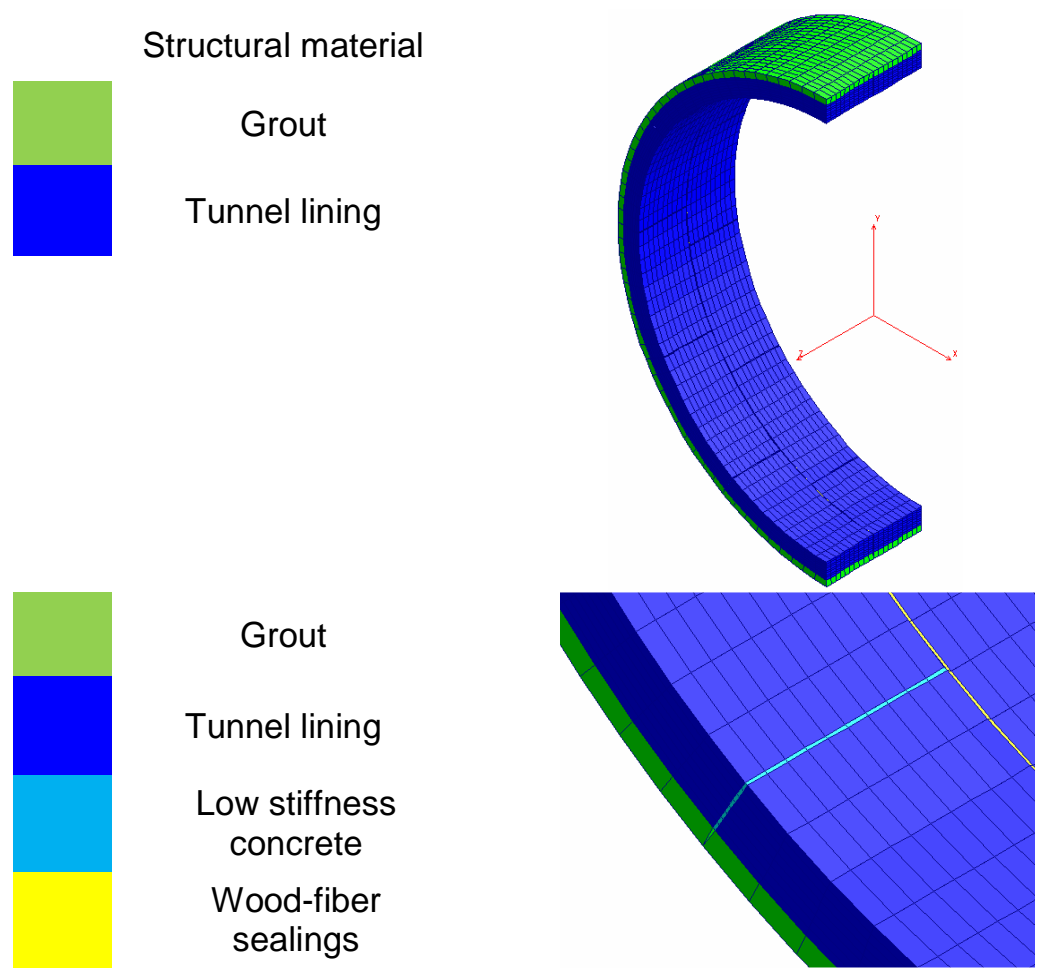

Fig. 3: Elements of computational finite elements model.

In transverse joints the gap between the units is filled with wood-fiber sealing excluding sections with intermittent connection as of "male-to-female" type. Adjacent to the lining is a $700 \mathrm{~mm}$ thick layer of grout.

The enclosing soil, concrete lining and sealing in joints are presented by SOLID elements. The rifled rods are presented by TRASS 3D elements. All elements of the model are loaded, the bulk weight of weak water-inundated ground being aligned with its waterborne condition.

Along the outer surface of the lining there is a distributed load caused by hydrostatic head of water, the latter being defined according to the tunneling conditions in the considered area. The hydrostatic head value is taken with account of the minimum water level in the river Neva.

The effect produced by a change in geological conditions along the tunnel route on the stressstrain behavior of precast lining was analyzed in the following way.

First, the stress condition was studied on the lining located within the soil whose properties corresponded to the geological conditions along the section (stress option \#1). This calculation resulted in the distribution pattern of normal circumferential stresses $\left(\sigma_{\theta}\right)$ in the lining rings (Fig. 4). 


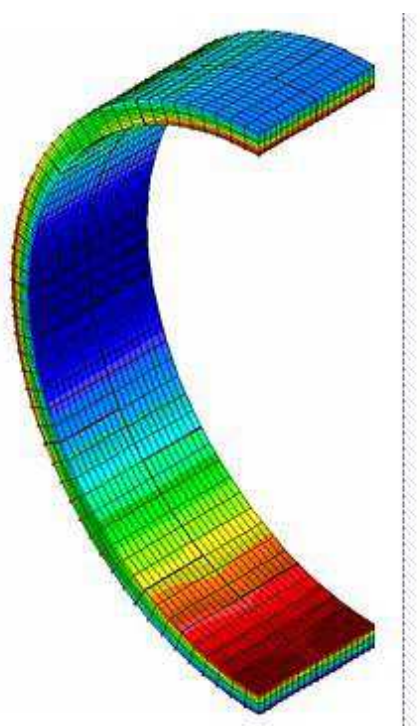

Stresses, $\sigma_{\theta} 10^{-2}(\mathrm{MPa})$

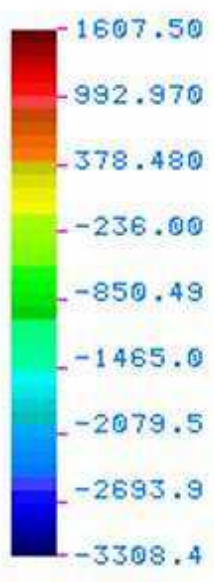

Fig. 4: Distribution of normal circumferential stresses $\left(\sigma_{\theta}\right)$ in the lining rings (stress option \#1).

Further, the stress condition was studied on the lining located within the soil whose stress-strain properties had been reduced 1.5 or 2 times compared to the original data and corresponded to the lowest values of these properties along the tunnel route (stress option \#2). This calculation resulted in the distribution pattern of normal circumferential stresses $\left(\sigma_{\theta}\right)$ in the lining rings (Fig. 5).

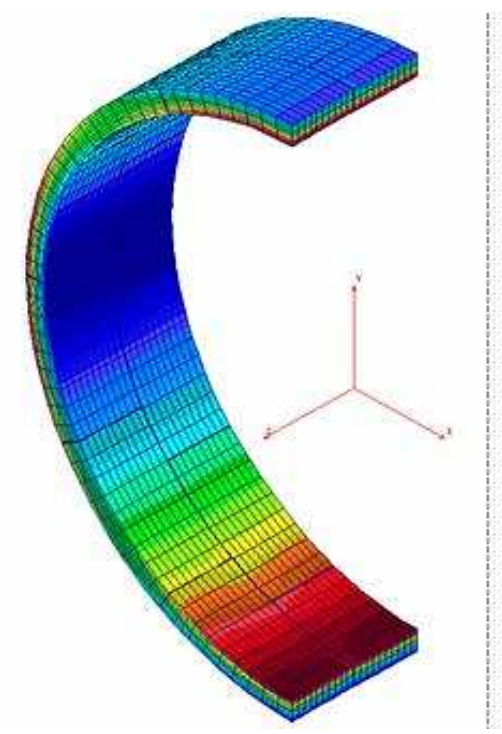

$$
\begin{gathered}
\text { Stresses, } \\
\sigma_{\theta} 10^{-2}(\mathrm{MPa})
\end{gathered}
$$

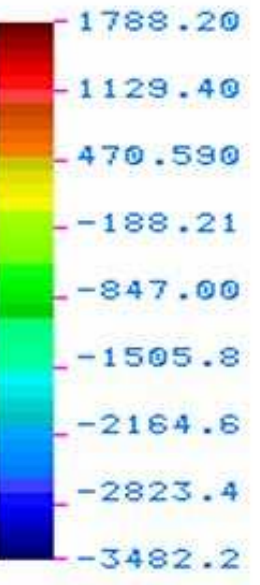

Fig. 5: Distribution of normal circumferential stresses $(\sigma \theta)$ in the lining rings (stress option \#2).

\section{Results of calculations}

The results of calculations having been compared, they showed that the reduction of stressstrain properties of the soil leads to a $25 \%(20 \mathrm{~mm})$ increase in vertical lining deformations as well as to a $5 \%$ and $11 \%$ increase in the maximum lining compression and tension stresses respectively. Moreover, the normal forces in the considered lining cross-sections increased by 2 - $6 \%$.

\section{Conclusions and recommendations}

The following conclusions can be made on the basis of the stress-strain behavior analysis of the large diameter tunnel precast lining performed using the finite elements method. 
A change in the stiffness coefficient of the lining joints, which accounts for the possible plastic hinges, has no substantial effect on the stress behavior of the structure but it influences its strain behavior. If the stiffness coefficient turndown is $1-0.10$, the lining deformations increase by $25 \%$. For this reason it is necessary to take a mean value of $K=0.5$ in the further analysis.

A 1.5 or 2 times change in stress-strain properties of the enclosing soil compared to the original values leads to a $5 \%$ and $11 \%$ increase in the maximum lining compression and tension stresses respectively. Moreover, the normal forces in the considered lining cross-sections increased by $2-6 \%$.

The results of the calculations show that the change in the stress-strain properties of soils along the tunnel route has no substantial effect on the stress behavior of precast modular lining because the stress turndown correlates with the accuracy of engineering calculations. However, a reduction in the soil stress-strain properties increases the precast lining deformations by $25 \%$. This can seriously affect the three dimensional condition of the structure and particularly the lining deformations and opening of joints in the areas of abrupt soil condition changes located along the tunnel axis.

Thus, the preliminary research in the static conditions of a large diameter underwater tunnel precast lining in St. Petersburg allows to conclude that such applications are possible. Nevertheless, it should be noted that one will need to provide further investigation of the effect produced by engineering geological conditions on the longitudinal strain behavior of the tunnel precast lining, both at construction and at long-term operation phase.

\section{References}

[1] www.herrenknecht.com

[2] www.AlaskanWayViaduct.org

[3] www.tunneltalk.com

[4] LEDYAEV, A. P. - GOLITSYNSKY, D. M. - KAVKAZSKY, V. N.: General issues of transport tunnels design and construction: A study guide (In Russian). PGUPS, Saint Petersburg, 2017, $72 \mathrm{p}$.

[5] LEDYAEV, A. P. - KAVKAZSKY, V. N. - KREER, R. O.: Peculiarities of tunnel design on highspeed railways (In Russian). Ural's Transport, 4 (47), 2015.

[6] IVANES T. V - KAVKAZSKII V. N. - SHIDAKOV M. I.: Geomechanical tasks solving in modelling of temporary support parameters in Sochi tunnels. Transportation Geotechnics and Geoecology, TGG 2017, 17-19 May 2017, Saint Petersburg, Russia.

[7] YELIZAROV, S. V. - BENIN, A. V. - PETROV, V. A. - TANANAIKO, O. D.: Static and dynamic calculations of transport and power supply facilities on the basis of COSMOS/M Software (In Russian). Saint Petersburg, Ivan Fedorov Typography, 2004, 260 p.

[8] BENIN, A. V.: The Finite Elements Simulation of Degradation Processes in Reinforced Concrete Structures (In Russian). Industrial and Civil Engineering, 5, 2011, pp. 16-20. 